\title{
Greened pedestrian linkage for Yangon central business district with its open spaces
}

\author{
Myo Thu Aung ${ }^{1}$, and Alexander Belkin ${ }^{1, *}$ \\ ${ }^{1}$ Moscow State University of Civil Engineering, 26, Yaroslavskoe Shosse, 129337, Moscow, Russia
}

\begin{abstract}
Yangon has passed a phase of rapid constructional development. This development has resulted in the growth of Yangon over its previous administrative boundaries and in tremendous changes of land use. Changes in land use have led to a growing number of environmental problems and a lack of infrastructure. The negative effects of spontaneous land use pattern, such as insufficient land use and damage of the natural resources along with the urban environmental problems of the mega-size urban area, can hardly be overcome after arising. They have to be minimized in advance by a foresight concept of efficient framework for land utilization pattern of future urban expansion in the Yangon City. This city has higher population density due to more accessible and positive economic situations than other areas. In this paper, the greened pedestrian linkage for Yangon Central Business District (C.B.D.), in which the largest number of colonial period buildings in Southeast Asia is located, is suggested. The essential requirements for the improvement and landscaping links are indicated, and this linkage may be an effective part of the green areas for the city's ecological framework.
\end{abstract}

\section{Introduction}

The article presents the problems of lack of recreation zone for Central Business District (CBD) and the results of a study of the possibility of developing a project of a greened pedestrian link for downtown area of Yangon, which connects historical colonial buildings, with its open spaces. The study is determined by the need for the development of greened pedestrian landscaped links, revealing the tourist potential of the city and at the same time being a part of its ecological framework.

The objective of the research is to develop a project of greened pedestrian linkage as a part of a system of Yangon greened networks not only for its tourist attractions but also for its good ecological system. The following steps were done for this research: study of city's urban problems with its populations and land uses, and the extensions of city, listing of parks, gardens, lakes and rivers, choosing objects of the historical and architectural colonial heritage, identifying the possibility of laying their connecting pedestrian route, finding out the possibility of landscaping and landscaping the route as part of a system of open green spaces in the city.

\footnotetext{
${ }^{*}$ Corresponding author: an.belkin@mail.ru
} 
Compared to many other countries in the region, Myanmar still has a predominantly rural population of around $71 \%$ and $29 \%$ of the total population of 60 million lives in urban areas. Yangon population is around 5.2 million in 2014. This means $37 \%$ of total Myanmar's urban population [1]. Yangon city served $10 \%$ of the total union population. With the present population growth rate of $3.4 \%$, Yangon populations will reach around 10 millions in year $2030[2,3]$.

Yangon City is the former capital of Myanmar, East longitude $96^{\circ} 13^{\prime}$ and north latitude $16^{\circ} 45^{\prime}$ run through on Yangon City. It is located at the confluence of Yangon and Bago rivers. It is situated on a flat low lying land at the southern end of Bago mountain range. The topography is a somewhat higher in the north and lower in the south, rivers such as Hlaing River are found on the west, Ngamoeyeik Creek on the east, Yangon River on the south and Pazundaung Creek on the south-east. The presence of these rivers and the nearness to the sea pose a challenge in keeping the city free of flooding. There are also lakes such as Hlawga Lake, Inya Lake and Kan Daw Gyi Lake.

Yangon is a port city, also has the Yangon International Airport and the central business area. Most of government organizations, private firms, universities and industries are concentrated in the Yangon City. It is organized by central business district (CBD), inner urban ring (IUR), outer ring (OR), south of CBD (SCBD), older suburb (OSU), northern suburb (NSU), and new suburb (NS).

It has 33 townships including CBD, which is formed with 7 townships and located along the Yangon River International port and harbors are located in CBD area (Fig. 1) [4].

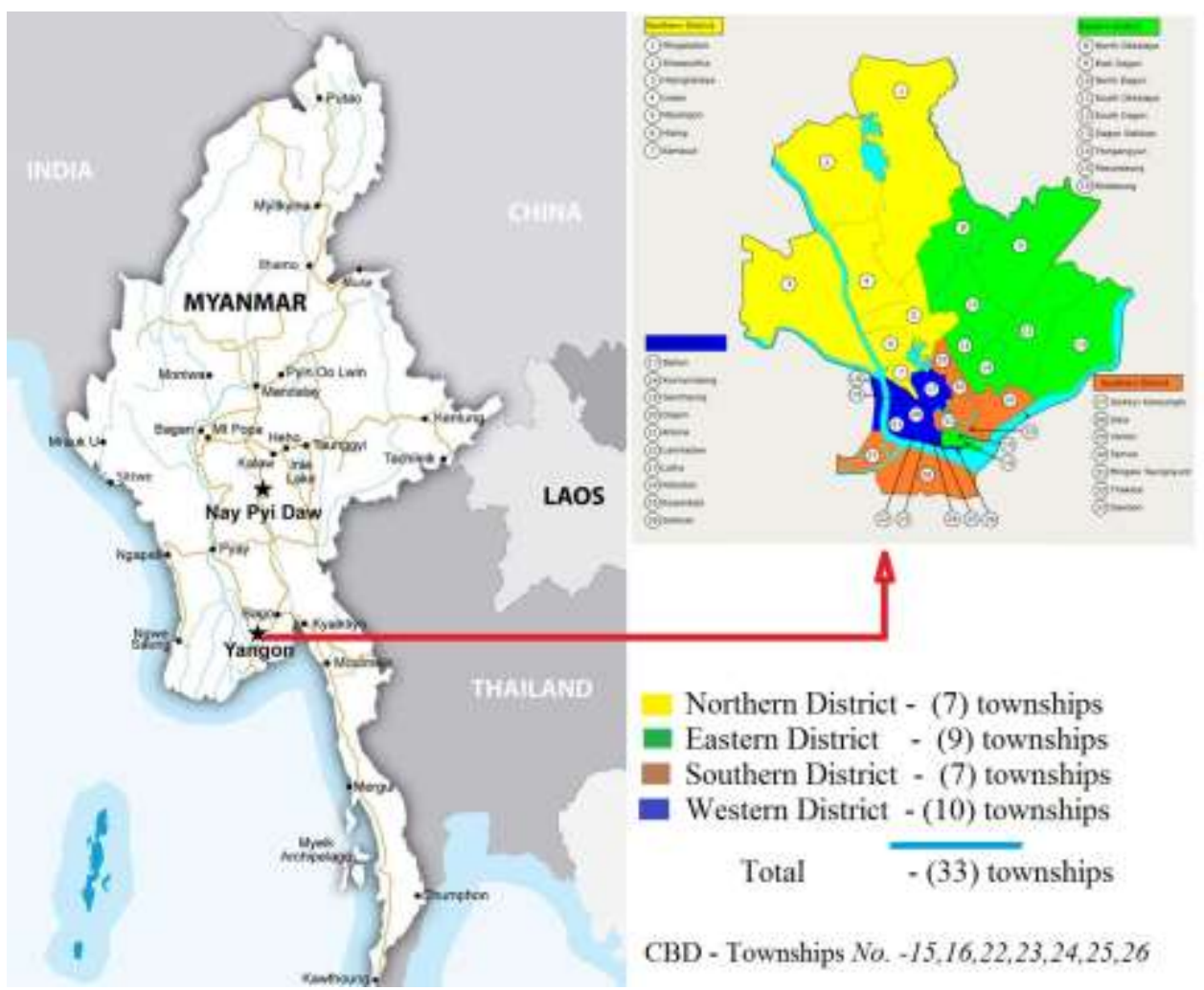

Fig. 1. Myanmar, Yangon City with its districts and townships. 


\section{Research methodology}

There are two data sources, primary and secondary data. Primary data were collected by observation method (field visits) and secondary data were collected from Yangon City Development committee (YCDC) and Department of Human Settlement and Housing Development. Additional data were collected from published and unpublished reports, research studies and articles by different researchers, line agencies and nongovernmental organizations (NGO).

Collected information using primary and secondary data collection methods were used in order to analyze qualitatively and quantitatively. Information regarding land use changes and existing urban expansion were analyzed by using charts: such as excels package, tables, maps and photographs.

The research is divided into four sections. The first section presents the current situation of land-use planning in Yangon City practicing in real recent development plan of Yangon district. The second section investigates possible high and low priority of central place function in Yangon city. The third section evaluates population growth, population distribution and projected population in Year 2020. Lastly, the fourth section covers some appropriate systems of greened pedestrian links for urban development and its future prospect to improve the current situation by suggesting and producing the gridlines for strategic Master Plan of CBD greened networks with its open spaces.

\section{Yangon city area development}

Yangon City was founded in 1755 by Myanmar king Alaungphaya and re-planned as the capital city of lower Myanmar in 1852 by the British colony for 50,000 inhabitants. The area of the city at that time was about 25.9 square kilometer (Fig. 2).

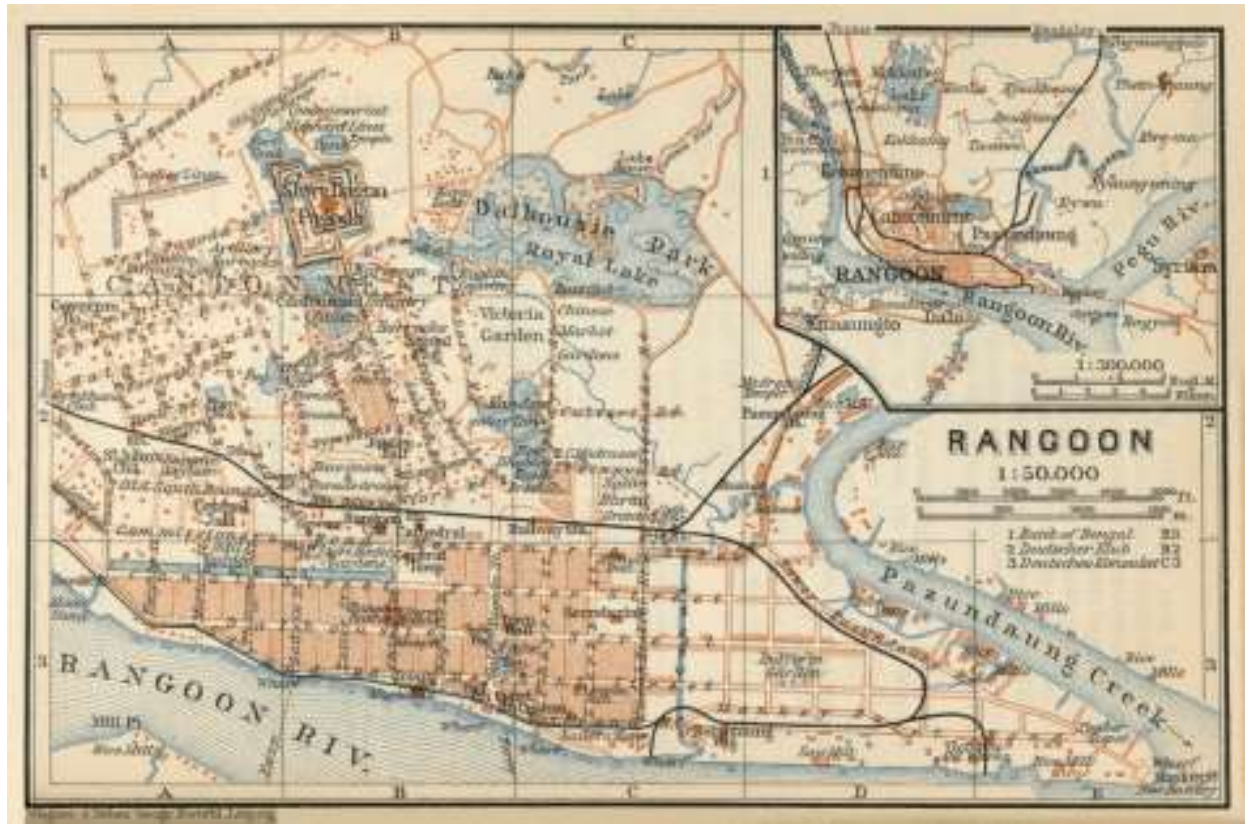

Fig. 2. Old Yangon (Rangoon) in 1914. 
In 1940, the city covered an area of 98.5 square kilometer with a population of 450,000 . Since then the city has grown to 3.5 million populations with 593 square kilometer in 1997 (Fig. 3) [5].

Due to the development of new satellite towns since 1987, the northwards sprawl of the city has changed to a cross pattern having an east-west axis and a north -south axis. The average population density of the city at present is 30 persons per hector, which is very low compared to other neighboring countries' capital city [6].

Large-scale urban development activities have been carried out in Yangon since 1989. Mixed-use developments have come to be undertaken in the central business district and in the areas vacated by large-scale squatter relocations. Isolated developments of great bulk are beginning to appear in the city. There are office buildings, hotels and housing. These three elements generally form the skyline of the intensively built up city. The city is divided into 33 townships, which may be grouped into three areas with different socio-economic settings as follows, (1) the Central Business District (CBD) with most of commercial and administrative activities; (2) the Sub-urban townships with commercial and industry establishments (3) new towns which are mostly residential and industry establishments.

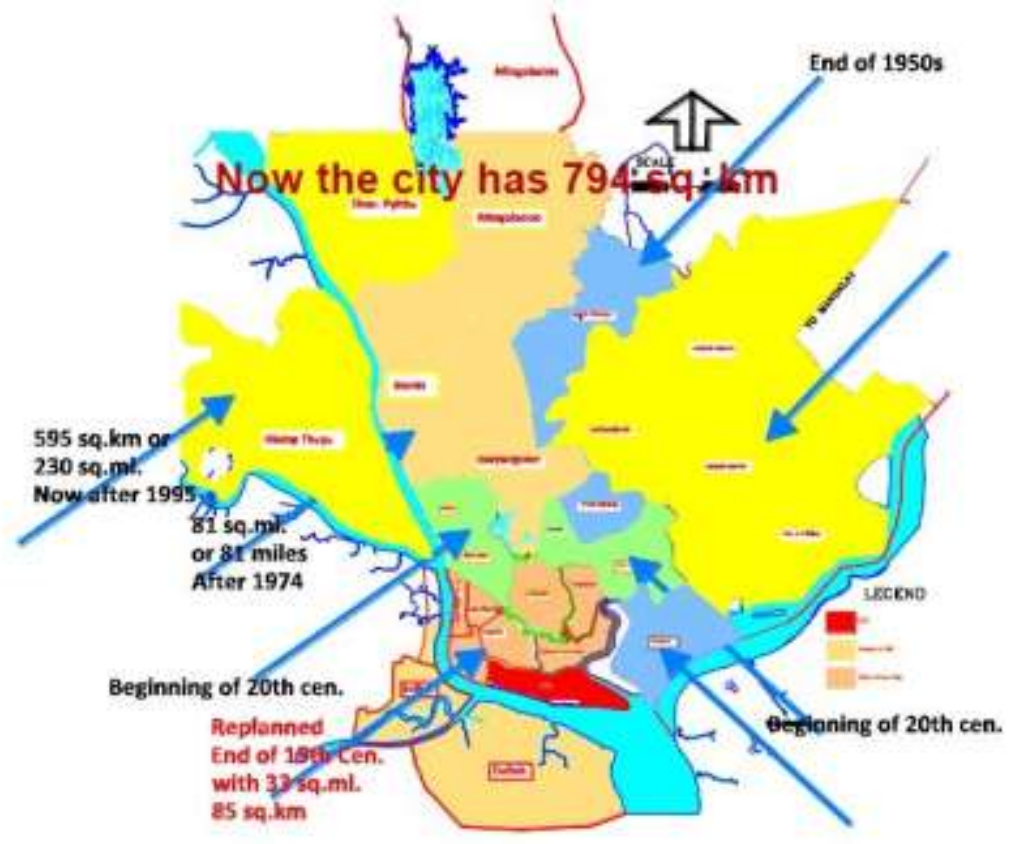

Fig. 3. Development of Yangon City.

\section{Yangon city characteristics}

Yangon, the former capital of Myanmar with a current population of 5,160,512 according to 2014 Myanmar population and housing census report and an area of $794 \mathrm{sq}-\mathrm{km}$ is administrative by the Yangon City Development Committee (YDCD). The primacy of Yangon is expected to remain as it is presently the most dominant city, accounting for more than 34.69 percent of the total urban population in the Union. Each decade after saw significant population growth, ranging from $22.2 \%$ to $22.4 \%$ annually. The population is expected to surpass 5.3 million in 2020 before climbing to 5.9 million in 2025 . The primacy of Yangon city is and important aspect in the overall planning of its future growth. The 
impact of a strong and sustained growth and structural changes will be strong on the city, since the dynamics of such growth is bound to enhance its primacy. For purpose of analysis, the Central Business District (CBD) will included the seven townships which are located intensity. These include (7) townships of Botataung, Kyauktada, Lanmadaw, Latha, Pabedan, Pazaungdaung, and Seikkan with land area of about $8 \mathrm{sq}-\mathrm{km}$. The population of CBD was 245,530 in 1983 and increased to 321,922 in 2003.

Table 1. Primacy Index for Yangon City (1983-2020).

\begin{tabular}{|c|c|c|}
\hline Sr. No. & Year & Primacy Index \\
\hline 1 & 1983 & 0.40 \\
\hline 2 & 1993 & 0.37 \\
\hline 3 & 2003 & 0.32 \\
\hline 4 & 2010 & 0.29 \\
\hline 5 & 2020 & 0.21 \\
\hline
\end{tabular}

Within the Yangon City (YCDC area) the 33 townships also demonstrate varying primacy index (PI) over the past years and is expected to improve during the planned period from 0.40 to 0.21 (1983-2020) with more balanced and equitable growth in the city region. This could be partly attributed to the resettlement program of relocating squatters to the suburban areas and the new towns developed by government. The projected population of the CBD is expected to increase slightly to 311,751 (2010) and 357,709 (2020). The Primary Index (PI) of the CBD however, is expected to fall further from 0.29 to 0.21 indicating that future population growth will be directed to the suburban areas as a result of the CBD being develop for commercial and office uses.

The present town ship character can be categorised in to Central Business District, Outer, Older Suburbs, Suburbs, New Towns and countryside. Central Place Function (CPF) of these townships have also been analyzed based on their economic activities, social services and facilities, transport and communication services and facilities, recreational activities, community organization, protective services, infrastructure and maintenance facilities and personal services. (See table -2)

Table (2) shows the benefits of central place functions based on the survey in the categorized zonal area of Yangon. In terms of the priority by benefits of CPF, Inner Urban Ring and Central Business District obtained high level benefits while other zonal areas are at moderate level in Yangon. Only one zone of South of CBD area is low benefit from CPF. But these townships are located at very near CBD.

Table 2. Central Place Function by Zone.

\begin{tabular}{|c|c|c|c|c|c|c|c|c|c|}
\hline \multirow{2}{*}{ Area } & \multicolumn{8}{|c|}{ Central Place Functions by $\%$} & \multirow{2}{*}{ Priority } \\
\hline & I & II & III & IV & V & VI & VII & VIII & \\
\hline CBD & 26.0 & 22.8 & 26.6 & 14.5 & 36.0 & 19.6 & 21.2 & 27.5 & $\mathrm{H}$ \\
\hline IUR & 23.5 & 25.5 & 22.0 & 29.0 & 22.9 & 23.3 & 28.0 & 24.0 & $\mathrm{H}$ \\
\hline OR & 11.5 & 12.4 & 12.0 & 15.7 & 8.0 & 13.7 & 14.0 & 16.0 & M \\
\hline SCBD & 2.0 & 4.8 & 4.1 & 4.3 & 1.7 & 2.6 & 2.7 & 1.8 & VL \\
\hline OSU & 10.5 & 9.3 & 9.1 & 12.6 & 9.9 & 9.7 & 11.2 & 7.7 & $\mathrm{M}$ \\
\hline $\mathrm{NSU}$ & 9.5 & 8.6 & 9.9 & 10.4 & 8.3 & 12.0 & 8.9 & 8.3 & $\mathrm{M}$ \\
\hline NS & 17.0 & 16.6 & 16.3 & 13.5 & 13.2 & 19.0 & 14.0 & 14.7 & $\mathrm{M}$ \\
\hline Total & 100 & 100 & 100 & 100 & 100 & 100 & 100 & 100 & $\mathrm{M}$ \\
\hline
\end{tabular}

Note: $\mathrm{CBD}=$ Central Business District, IUR=Inner Urban Ring, OR=Outer Ring, SCBD=South of CBD, OSU=Older Suburb, NSU=Northern Suburb, NS=New Suburbs, VH=Very High, H=High, 
M=Moderate, L=Low, VL = Very Low, I=Economic Activities, II=Social Services and Facilities, III=Transport and Communications Services and Facilities, IV=Recreational Activities, $\mathrm{V}=$ Community Organization, $\mathrm{VI}=$ Protective Services, VII=Infrastructure and Maintenance Facilities, VIII=Personal Services.

\section{Population growth and distribution of Yangon city}

The total population of Yangon City is estimated to be about 4.35 million in 2005, with an average growth rate of 2.5 percent during 1983-2005 periods. The rate of population growth increased from 2.87 percent during the 1993-2005 periods to 3.4 percent during 2005-2014 periods. The population growth of Yangon City was higher that Yangon Division is 2.4 percent and Union of Myanmar is 2.2 percent. The higher growth of Yangon City population was attributed to migration from rural areas of Yangon Division (Outside City) and from other states [6].

The distribution of Yangon City population according to townships is shown in appendix. Population was largely concentrated in several townships such as Insein, Thingangyun, Tharkayta, North Okklapa, South Okklapa, Hlaing, Mayangone and Mingalardon. Population growth of the townships varies.

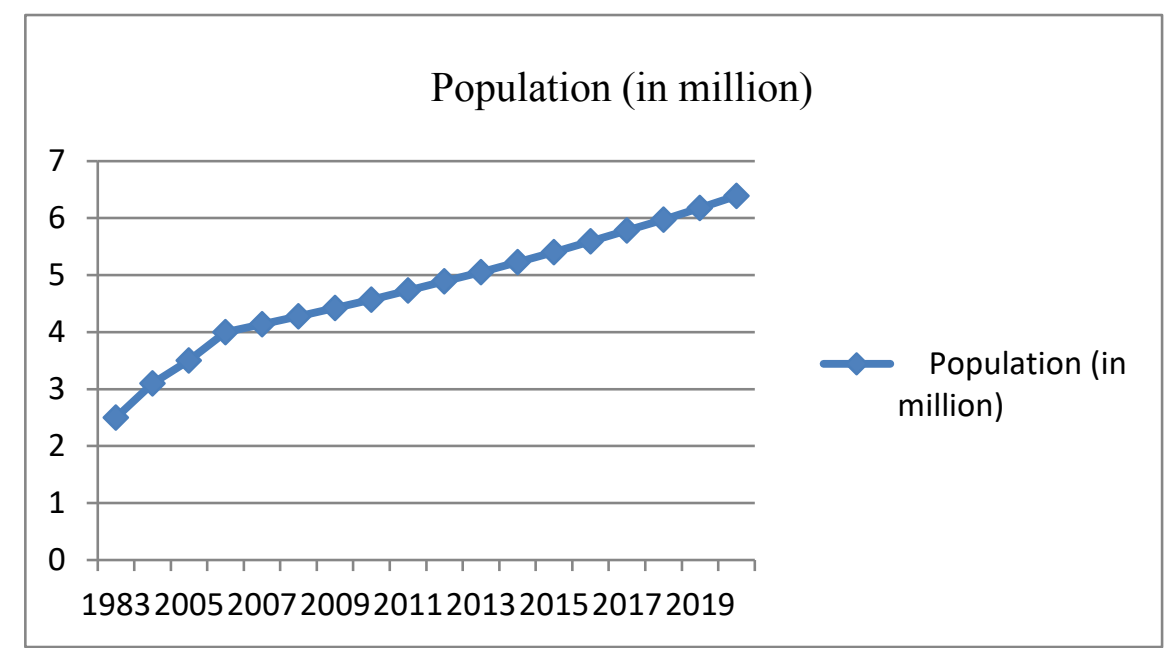

Fig. 4. Projected population of Yangon, 2010-2020.

The growth of Inner City Area has low growth rate less than 1 percent per annum. On the other hand the townships located at the fringes towards north-west and eastern part of Yangon City has experienced rapid increased in population with growth rate of more than four percent. These are the areas where future direction of growth shall be expected. The population is projected to rise to about 6.8 million by 2020, with an average growth rate of 3.4 percent.

The increase is largely due to net in-migration to the city of about 200,000 per annum. The rate of increase due to birth is about 31,000 per annum.

The population of the townships located at the eastern and western fringes of the cities is expected to grow more than four percent per annum while the population of older townships located in and around the inner city is projected to increase much slower (less than 2.0 percent). These inner city townships have limited area for future expansion and the density is already high. 


\section{Yangon's potential}

Yangon can become a centre of learning and knowledge-based economies; a regional hub of innovation, creativity, skill and new technologies. It can attract and keep national and international talent by providing a beautiful and well-planned city. This, along with access to venture capital, fast internet and good infrastructure will allow Myanmar's economy to diversify beyond low-income sectors. Yangon can take advantage of the global shift towards knowledge based economies just as the Asian region is growing quickly [7]. Yangon can be a place all Myanmar people feel at home and play an essential role in building a more unified nation; its schools, universities and offices can attract young people from across the country to live, study and work together. Yangon can be a beacon of religious and cultural diversity; home to hundreds of places of worship, representing all the world's major religions, it can showcase harmonious inclusion of diverse cultural backgrounds, world-views, lifestyles, relationships, business and problem-solving skills and be a meeting place across cultures and religions [8].

Emerging out of decades of isolation, Yangon can once again be a global city; since its 18th century founding, it has been Myanmar's window on the world. In 15 years it can be a regional hub for public and private sectors, business and learning and inter-governmental and civil society initiatives in Southeast Asia. Yangon can be an extremely liveable city; healthy, happy, beautiful and modern, with park systems, an expansive waterfront, upgraded infrastructure, and its built and cultural heritage intact. Undertaking the major infrastructure upgrades needed to meet the challenges and opportunities of the coming century is achievable. Ensuring that the city doesn't destroy what will make it liveable, regionally competitive and economically successful is the challenge for urban problems. This can be achieved through good urban planning, careful heritage conservation and good city administration. The Strategy section of this document suggests what can be done immediately and over the coming years to begin to realize this vision [9].

\section{Colonial architecture of Yangon}

Yangon is the former capital and largest city of Myanmar, the former Burma. Myanmar with a population of 52 million is considered one of the most beautiful countries in Southeast Asia and it has own rich architectural history. In the history of Myanmar in the period from 1823 to 1886 there were three Anglo-Burmese wars, after which from 1886 Burma became a colony of Great Britain. From 1886 to 1948 is the British Colonial period. After the second war, the British took the most parts of Burma, including Yangon. The city became the administrative capital of Lower Burma in 1852. Then, after the British annexation of Burma in 1886, Yangon became the capital of the whole country [10].

The architecture of Yangon City includes religious buildings: temples, pagodas, stupas belonging to the XI-XXI centuries; residential buildings with traditional architecture, which were built from bamboo, palm leaves and other auxiliary material without any plans, projects and drawings, and on the "model", as is typical for folk architecture; and buildings of colonial architecture. Yangon has the highest concentration of colonial buildings in the Southeast Asia, most of which have survived to the present. Hundreds of buildings of the late XIX century are located on an area of several square kilometers in the city center CBD. 


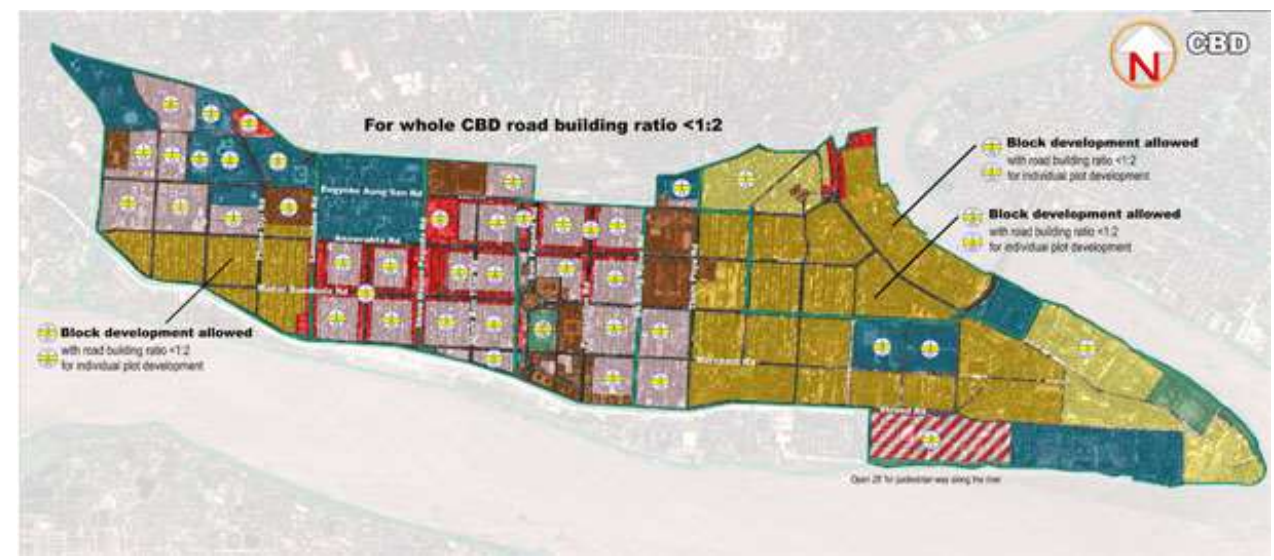

Fig. 5. CBD of Yangon.

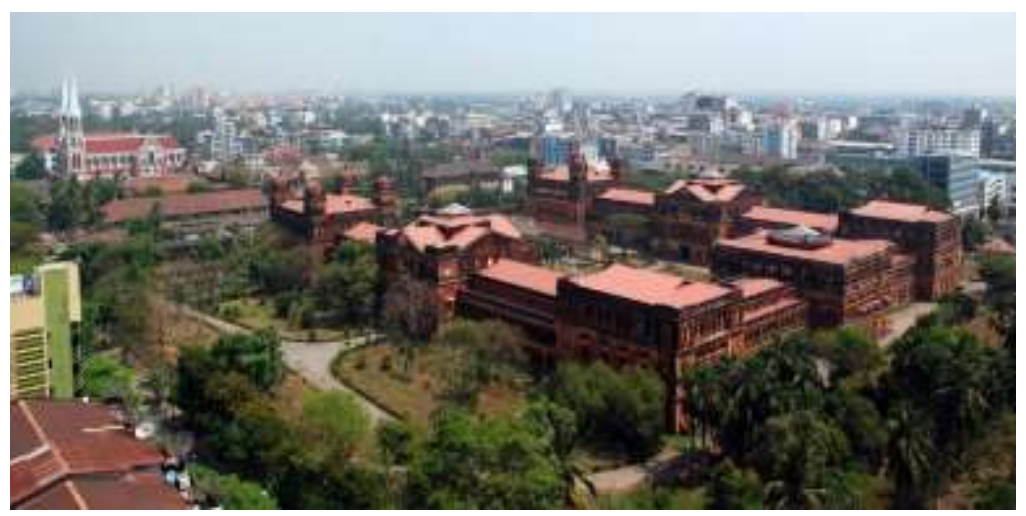

Fig. 6. Secretariat (A complex of colonial administrative buildings).

A large number of impressive buildings in the Victorian style, the styles of Queen Anne, Art Deco, British-Burmese and neoclassical style were built by the British.

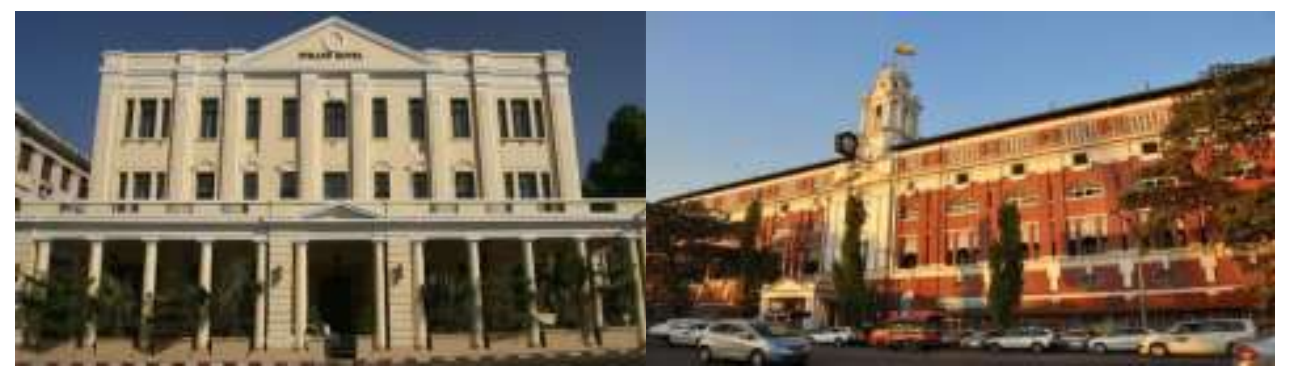

Fig. 7. Hotel "Strand (left) and Customs House (right).

The Yangon colonial buildings, built at the end of the 19th century, are truly unique in their various styles and structures. The most famous and well-preserved of them are the Secretariat (Fig. 6), the Strand Hotel, the Custom House (Fig. 7), City Hall, Yangon Stock Exchange (Fig. 8), Render House, the Port Authority of Myanmar (Fig. 9), Bogyoke Aung San Market, High Court (Fig. 10).

The British primarily needed only suitable buildings for their own living and administrative management, as they did not want to live and work in traditional Burmese 
houses. The British started the building construction with reinforced concrete structures of in the English style, to which they are accustomed to in England. They built many buildings with a fireplace and hermetic windows, with glass to protect against insects, etc. As a result, administrative buildings (banks, business centers) and industrial buildings (factories, companies, warehouses), as well as residential buildings and hotels were built with their own styles.

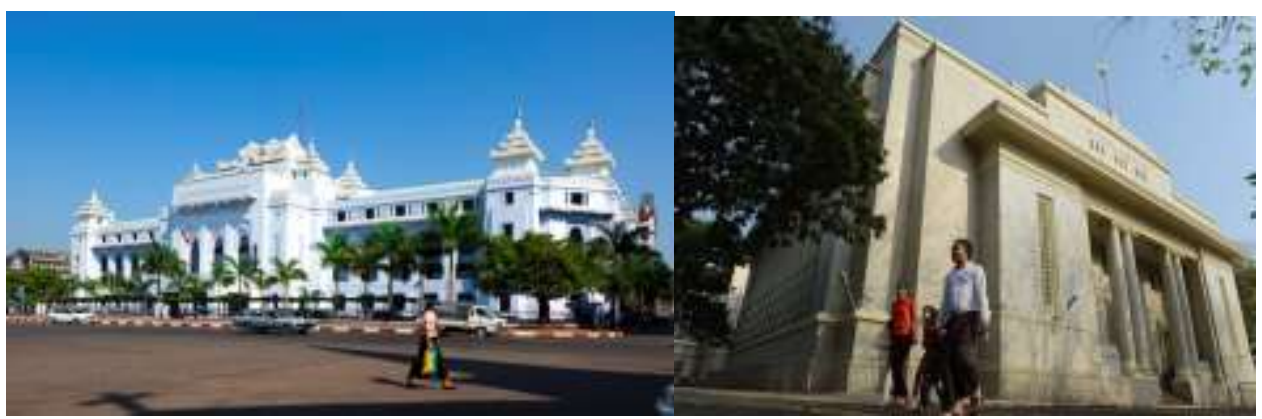

Fig. 8. City Hall (left) and Yangon Stock Exchange (right).

However, during the first 50 years, the discrepancy between the English buildings and the climate of Myanmar was found. In the British Isles is relatively dry and cold, and in Myanmar, especially in Yangon, warm and humid. Since the windows of the houses were closed hermetically, there is no necessary air exchange and ventilation inside the house, high humidity is observed. The microclimate of residential and public premises in them does not correspond to the comfort indicators, therefore now in the colonial buildings of Yangon the windows are almost always open, while the British prefer to keep the windows closed.

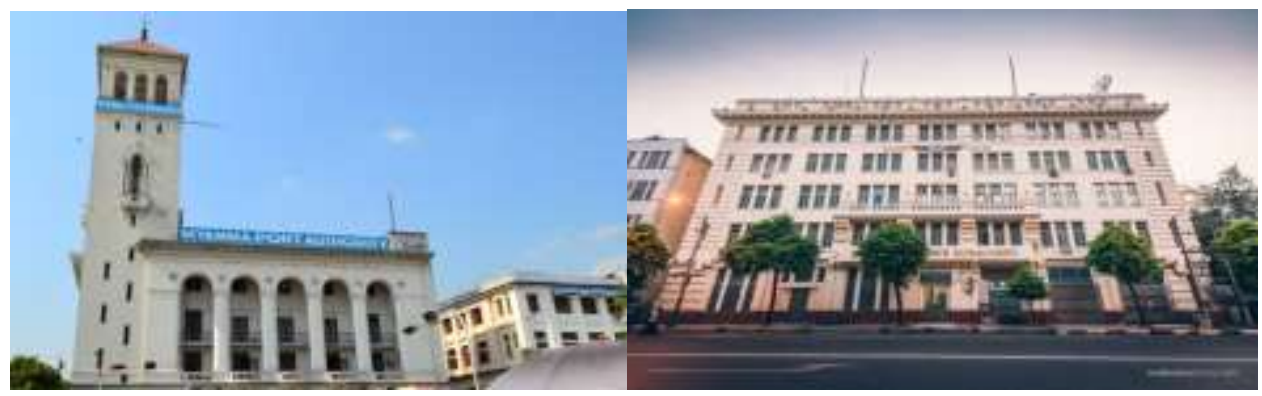

Fig. 9. Myanmar Port Authority (left) and Render House (right).

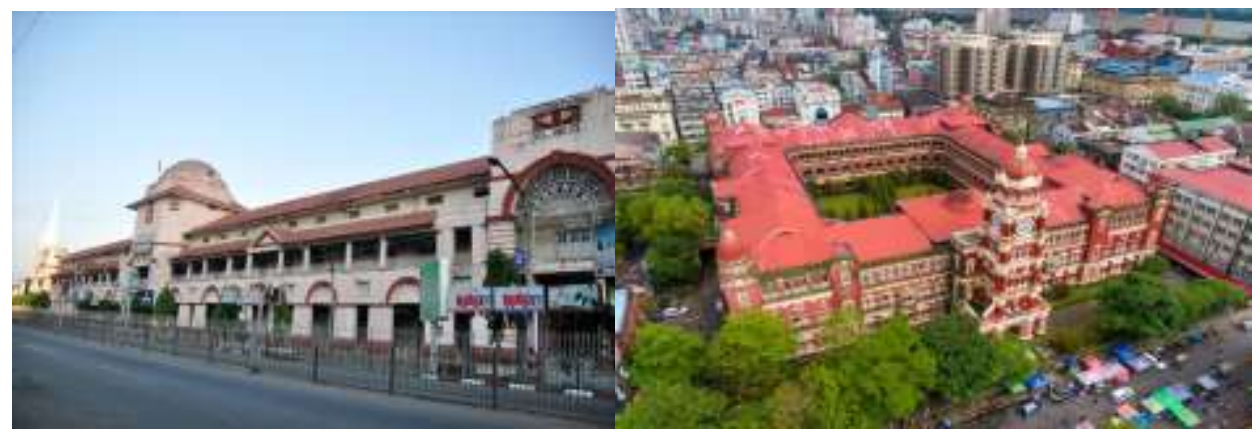

Fig. 10. Bogyoke Aun San Market (left) and the High Court Building (right). 
When Myanmar was liberated, and the Burmese began to build their own buildings in Yangon and other cities, the shortcomings of English houses became apparent. In the first years of independence, there was a shortage of funds, construction developed slowly. In recent years, high-rise many apartment buildings of mass construction were built with the suitable climatic features.

\section{Yangon's urban situations and green problem of CBD}

Yangon can be Asia's most liveable city. Continuing as Myanmar's commercial capital and green city, it can also be a centre of arts and culture, creative and knowledge based economy as well as for new manufacturing and service industries. With improved industrial areas, new air and sea ports with transport links across the country and the globe, Yangon can lead the country's growth. It can also be a top international tourist destination and a global example of inclusion of cultural diversity. Undertaking the major infrastructure upgrades needed to meet the challenges and opportunities of the coming years is achievable. The solution lies in careful heritage conservation and good urban [11].

Urban planning is the process of designing how best to effectively use, protect and manage a city's assets and how best to address its challenges. This process involves preparing for the future through a set of proven principles and processes that have worked in other urban contexts. Urban planning can apply at a very local scale or at a comprehensive scale across a whole city. This type of plan is called a master plan and involves looking at all of a city's systems and how they relate to each other, and strategically preparing actions and guidelines for their management [12]. A master plan may contain many specific plans for issues such as sanitation or transportation. Until the early 1960s, Yangon was well managed under the guidance of good urban planning principles. Since 1990, several poor decisions including the Strand toll road, badly placed towers like Centre point and the HAGL Myanmar Centre, new road overpasses and the downtown pedestrian footbridges have further damaged the urban environment [13].

Many cities are now experiencing huge social, economic and health problems due to unplanned development that has led to physical and economic isolation of outer urban areas. In such cities, slums entrench the social gap between rich and poor, traffic becomes gridlocked for hours and access to new job and education opportunities is minimal. Poor infrastructure means high levels of noise and air pollution, rivers clogged with rubbish, piles of garbage in the streets, and lack of hygiene from congested sewers or water drains. All this leads, in turn, to a downward cycle of investment as investors choose to take their business elsewhere. Without good planning, Yangon could end up like this within a few years [14].

In the CBD of Yangon, there is only one park called Mahabandoola which is located in the center of downtown area near Sule pagoda ( Fig. 208-m x 142-m) for the peoples' recreation [15]. Nowadays, in the CBD of Yangon, the lack of adequate green areas is the one of the urban problems of city (Fig. 11). The people are going for their recreation to the parks, gardens and lakes which are located from the city's centre with the distance of 2.5 $\mathrm{km}$ to $3.5 \mathrm{~km}$. The population of CBD was 321,922 in 2005 and increased to 544,615 in 2014. In the CBD population density is about 681 people per hectare (681 pop/ha). So the many urban projects and attractive and comfortable urban spaces with high quality design are needed to grow and to develop. My research paper will solve a part of these urban problems. 


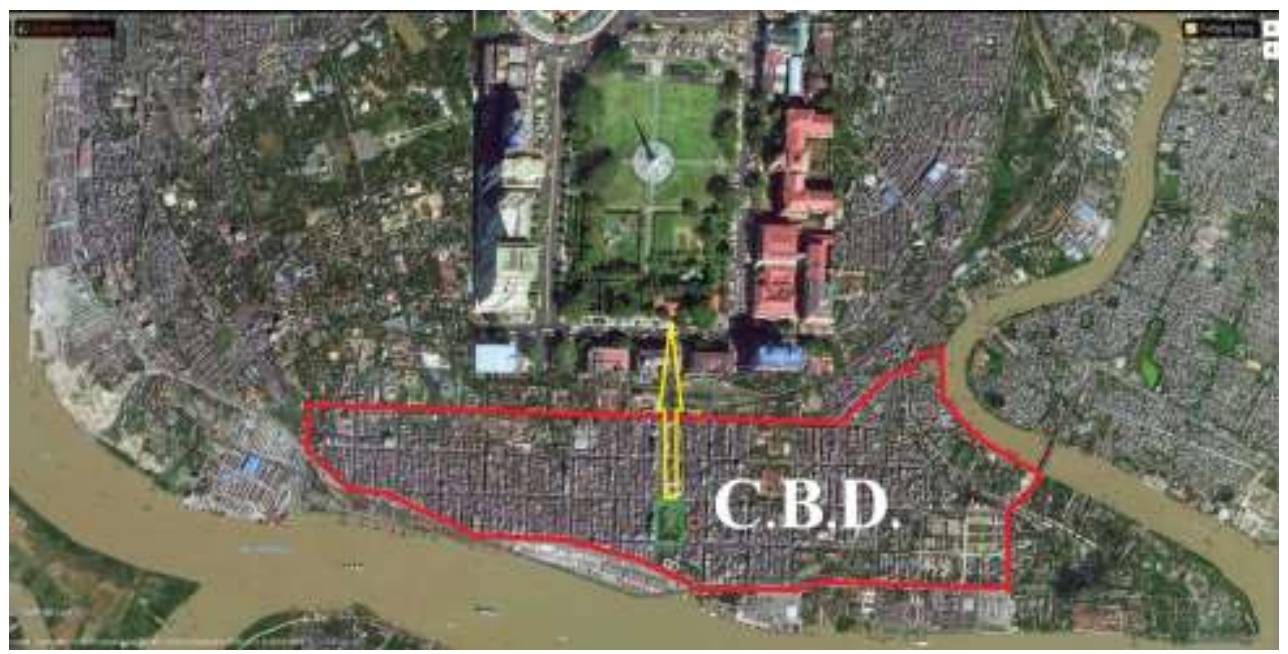

Fig. 11. CBD with its only one Park (Mahabadoola Park).

Distances between Mahabandoola park and others open spaces (parks, gardens, and lakes) are as follows (Fig.12)

1. Mahabandoola park - Seikkantha park

$(0.41 \mathrm{~km})$

2. Mahabandoola park - Ministers' office

$(0.55 \mathrm{~km})$

3. Mahabandoola park - Yangon Zoologiczl Garden

$(1.7 \mathrm{~km})$

4. Mahabandoola park - Kandawgyi lake and park, and Bogyoke park

$(2.3 \mathrm{~km})$

5. Mahabandoola park - Kantawmin lake

$(2.3 \mathrm{~km})$

6. Mahabandoola park - Thakhinmya park

$(2.5 \mathrm{~km})$

7. Mahabandoola park - Shwedagon pagoda's complex

$(2.6 \mathrm{~km})$

8. Mahabandoola park - People's square and park

$(2.8 \mathrm{~km})$

9. Mahabandoola park - Pyitawtha lake

10. Mahabandoola park - Yangon Region Parliament

$(3 \mathrm{~km})$

11. Mahabandoola park - Pyitawtha park

$(3.2 \mathrm{~km})$

$(3.3 \mathrm{~km})$

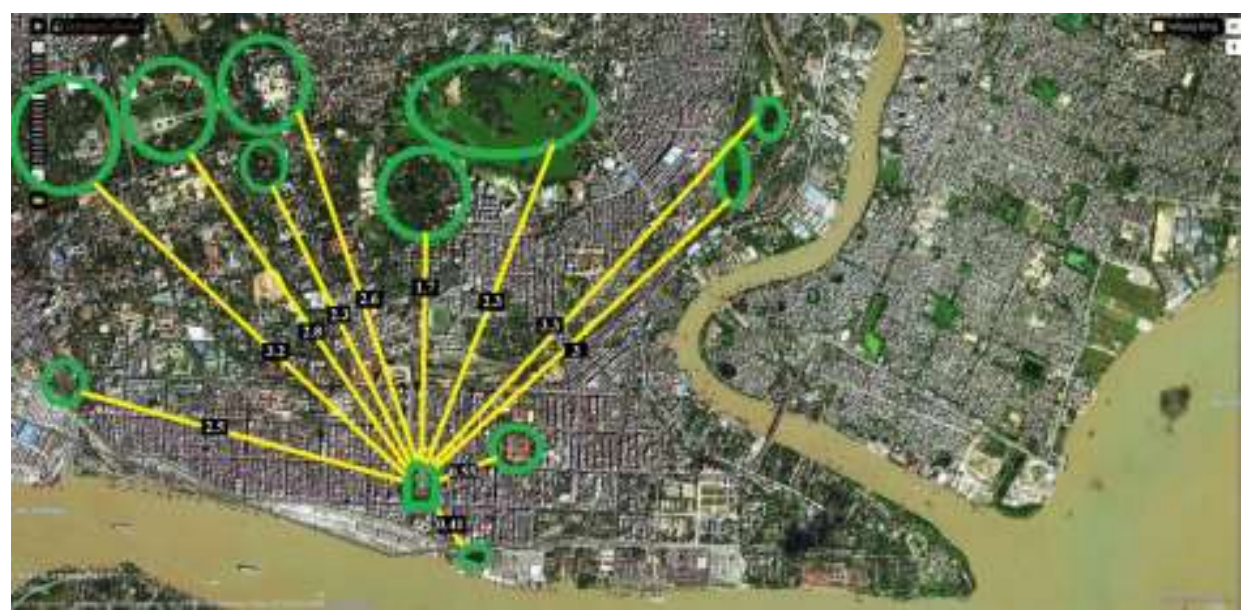

Fig. 12. Distances between Mahabandoola park and others open spaces (parks, gardens, and lakes). 


\section{Proposal greened pedestrian links and recommendations}

Variety aspects of the urban spaces where different historic buildings and religious monuments of different ages are built in one place in the CBD. For the improvement of the city, together with the conservation of the buildings, it is effective to convert their usages into another new context that will be utilized by the citizens. In order for tourists or citizens to enjoy these attractive urban spaces, it is recommended to develop attractive and comfortable urban spaces with high quality design. It is effective to form attractive urban spaces in both day and night. Together with intangible activities such as cultural policy, invitation for the attractive events, development of tourist routes, etc, multilateral measures will be required for the development of tourism.

\subsection{Proposal - 1}

Because of the presence colonial heritage buildings and their obvious architectural and historical values, they should be preserved and we can propose the effective projects for both tourists and local people. It will also help to be a green city with better environment. Based on the analysis of the location of the colonial heritage buildings, a greened pedestrian linkage with the colonial old Yangon was proposed and designed with a length of about 7.5 $\mathrm{km}$.

The proposed greened pedestrian linkage, containing historical and cultural heritage 16 objects can be actualized; the route needs the many arrangement of recreation areas, additional landscaping and navigation; the route may be a part of the system of green areas for the city's ecological framework. The project to create pedestrian green linkage along unique colonial buildings will contribute to the development of tourism in Myanmar. The result is really effective not only for the foreigners, but also for the development of tourism for local residents. The 16 objects which will include and we can see with this linkage are listed in table (3). The City hall is the start of linkage and the end will be at the Sule pagoda (Fig. 13).

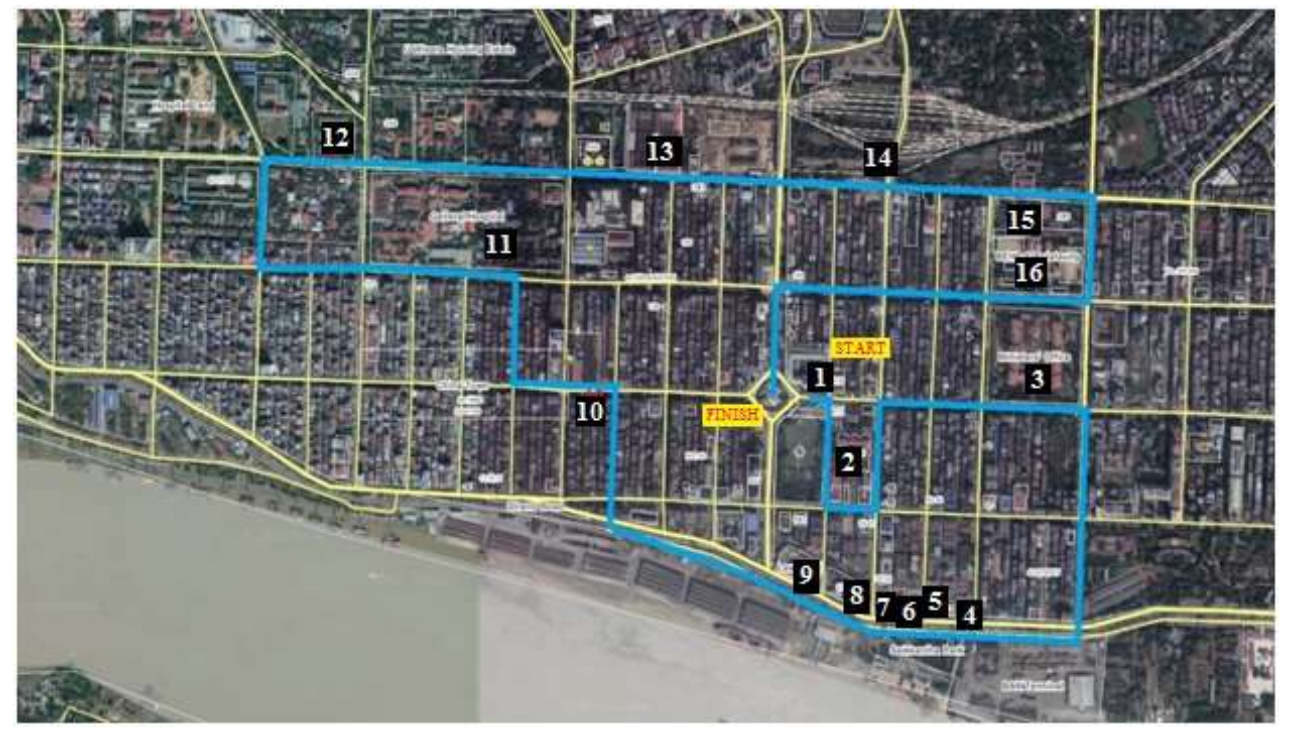

Fig. 13. Proposal greened pedestrian linkage through the colonial Yangon.

Table 3. Some of Colonial Heritage Buildings in CBD. 


\begin{tabular}{|l|l|}
\hline 1. City Hall & 9. Court of Yangon Region \\
\hline 2. High Court & 10. Theingyi Market \\
\hline 3. Secretariat & 11. Central Hospital \\
\hline 4. National Post's Office & 12. University Medicine №1 \\
\hline 5. Strand Hotel & 13. Bogyoke Aung San market \\
\hline 6. Bombay Burma Company 1 & 14. Central Railway Station \\
\hline 7. Myanmar Port Authority & 15. Saint. Mary's Catholic Cathedral \\
\hline 8. Custom House & 16. B.E.H.S No.6 Botatung \\
\hline
\end{tabular}

\subsection{Proposal - 2}

The CBD and open spaces of parks, gardens and lakes are connected by the old roads as an outer ring of CBD. The proposed greened pedestrian linkage, containing CBD of Yangon with its open spaces can be actualized; the linkage needs the many arrangement of recreation areas, additional landscaping and navigation; the linkage may be a part of the system of green areas for the city's ecological framework. The project to create pedestrian green linkage along unique colonial buildings will contribute to the development of tourism in Myanmar. The result is really effective not only for the foreigners, but also for the development of tourism for local residents (Fig. 14).

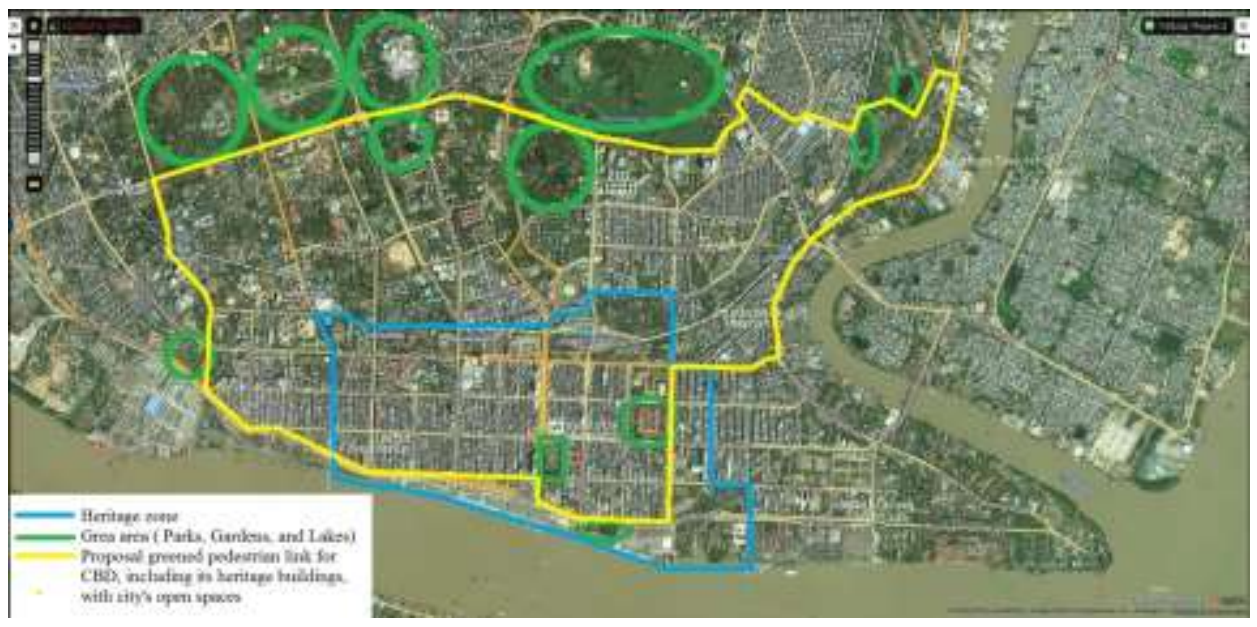

Fig. 14. Greened pedestrian linkage for CBD, including its heritage buildings, with city's open spaces.

\subsection{Proposal - 3}

The CBD and city's open spaces of parks, gardens and lakes by an Ellipse-shaped ring linkage as inner ring and outer ring placing open spaces between them. The proposed greened pedestrian linkage can be realized; the linkage needs the many arrangement of recreation areas, additional landscaping and navigation; the linkage may be a part of the system of green areas for the city's ecological framework. The project to create pedestrian green linkage along unique colonial buildings will contribute to the development of tourism in Myanmar. The result is really effective not only for the foreigners, but also for the development of tourism for local residents (Fig. 15). 


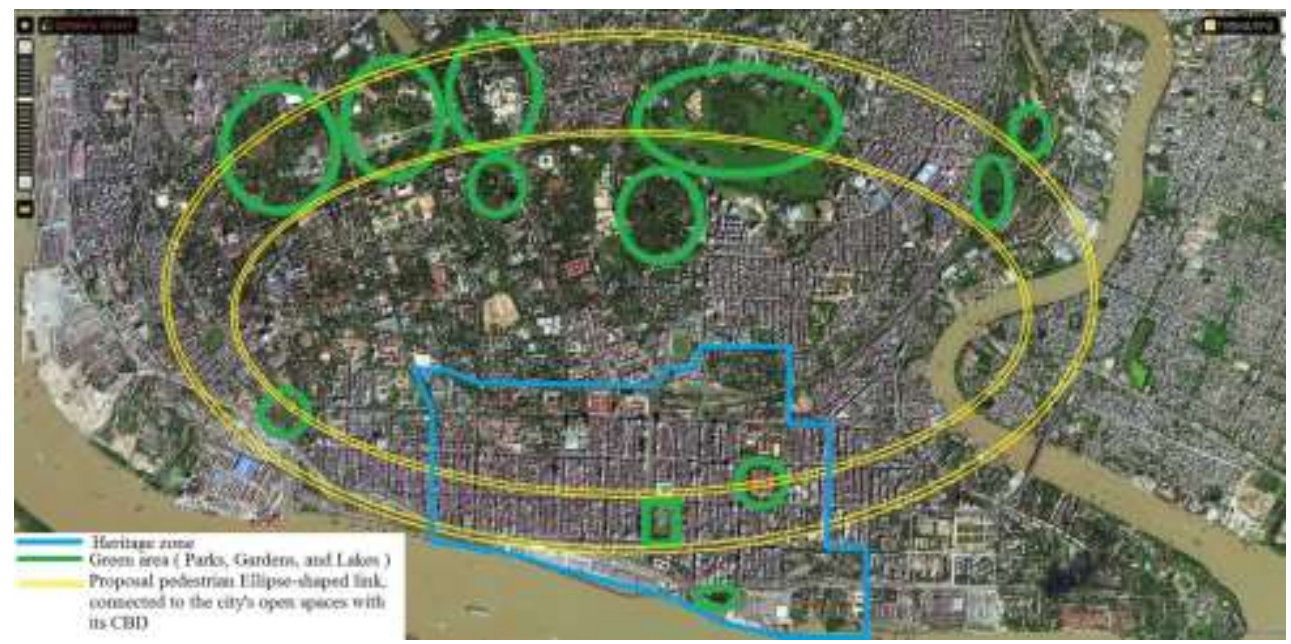

Fig. 15. Greened pedestrian Ellipse-shaped linkage, connected to the city's open spaces with CBD.

\subsection{Proposal - 4}

The CBD that includes its recreation areas and heritage buildings, and city's open spaces of parks, gardens and lakes by old roads, streets and passages. The proposed greened pedestrian linkage can be realized; the linkage needs the many arrangement of recreation areas, additional landscaping and navigation; the linkage may be a part of the system of green

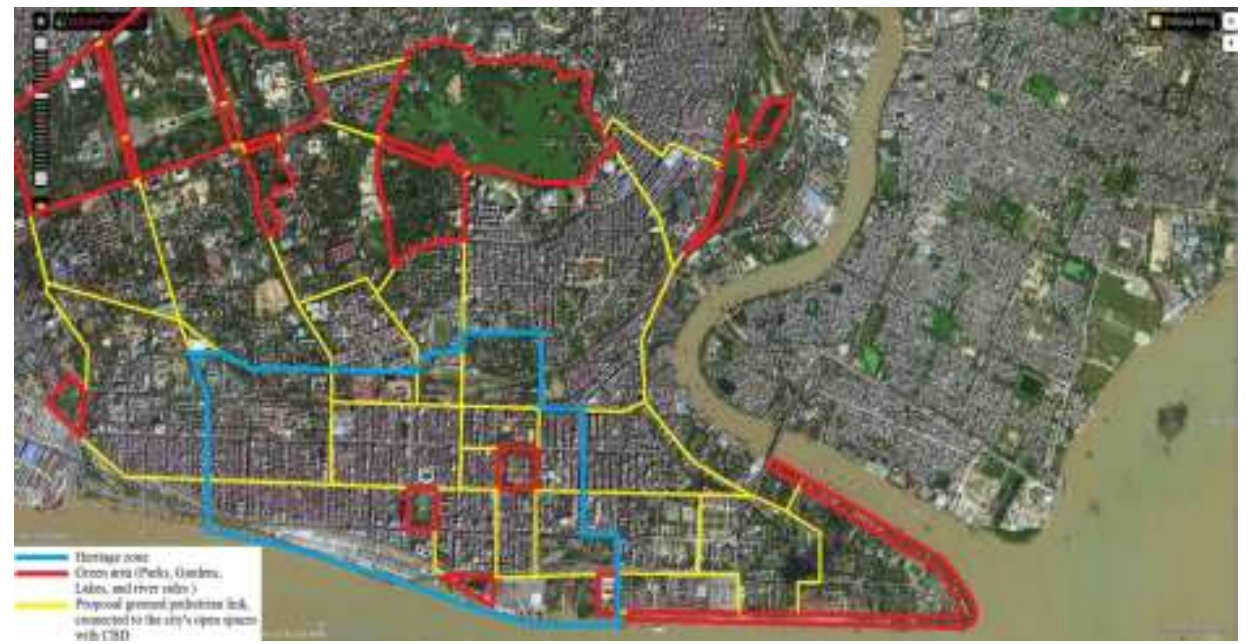

Fig. 16. Greened pedestrian linkage, connected to the city's open spaces with CBD.

areas for the city's ecological framework. The project to create pedestrian green linkage along unique colonial buildings will contribute to the development of tourism in Myanmar and urban planning. The result is really effective not only for the foreigners, but also for the development of tourism for local residents (Fig. 16). 


\section{Conclusion}

Yangon is and will be one of the most important urban centres of Myanmar. The city has grown rapidly in recent years and new suburban satellite townships have been development by the government to accommodate the increasing population and resettle inhabitants from the congested inner CBD area.

To maintain the image of Yangon as a livable and sustainable city, there is an urgent need to establish comprehensive city planning and urban development law. This law should be a comprehensive law covering aspects related to the use, development and conservation of land and building in the city. This law should be cover aspects pertaining to the types of Statutory Development Plans, Urbanization Promotion Areas, Land Readjustment, Land and Building Development Control, Planning Proposal Reports, Environmental Impact Assessment, Social Impact Assessment, Heritage Buildings and Conservation Areas including Environmentally Sensitive Area, public participation, enforcement as well as appeal procedures. In addition to planning laws, it is important to establish rules and guide lines.

This article suggested and pointed out the essential requirements of greened pedestrian networks of people's recreation and for a good city's ecology system. These 4 proposals greened pedestrian linkages with an additional landscaping and navigation not only can help to be a better system of green areas for the city's ecological framework but also effectively solve the lack of recreation zones for the residents and citizens.

\section{Acknowledgement}

The author is grateful to his dissertation supervisor on Ph.D study, Belkin Alexander Nikolaevich, professor, department of architecture NRU MGSU for the encouragement to do this work. The author wishes to express his gratitude to the all colleagues of department of architecture. The author also delivers his sincere thanks to the DHSHD and YCDC for providing necessary data, facts and figures. Finally, the author would also like to express his gratitude to all officials and experts, who provided him useful information and suggestions to complete this work.

\section{References}

1. Tin Tin Pyone, "Urban Development in Myanmar" to seminar report 11th International Seminar on Land Readjustment and Urban Development (Japan, 2002)

2. Mie Mie Tin, "New Opportunities for Housing in Yangon Mega City”, Seminar report German Myanmar Workshop on Sustainable and Urban Development in the Mega City Yangon (Yangon University, Myanmar, 2005)

3. Malaysian Industry Government Group for High Technology and Institute of Sultan Iskandar, "Yangon Strategic Development Plan (Interim Report)" (YCDC, Yangon Myanmar, 2005)

4. Myanmar Maps, http://myanmarmaps.com/

5. San San Moe, GMSARN International Journal 3, 179-186 (2009)

6. Department of Population Ministry of Labour, Immigration and Population with Technical assistance from UNFPA, "The 2014 Myanmar Population and housing census" (2014) 
7. Yangon Heritage Trust, "The Role of Heritage in the Sustainable Development of Yangon”, Building the Future, Report of an International Conference held in Yangon (Myanmar, 2015)

8. Yangon Heritage Trust, Yangon Heritage Strategy 1, 152 (2018)

9. UNDP Myanmar, The State of Local Governance: Trends in Yangon (2015)

10. B. Bansal, E. Fox, Yangon: Architectural Guide, DOM Publishers (2016)

11. Yangon Region Government (YCDC), Yangon 2040 An Attractive International Port and Logistics Hub: The City of Blue, Green and Gold (2016)

12. Rogier van den Berg, Guidelines for Urban Planning (2016)

13. Hnin Su Mon Win, Maung Hlain, Theingi Shwe, Comparison between Green Area Ratio of Yangon's Housing Estates and Foreign Housing Estates, IJETAE 4(2) (2014)

14. Dr. Su Su, "Liveable Cities- Myanmar Experience: Approach Systematic Urban and Management System of Yangon Central Business District”, Toward Liveable CitiesThe ASEAN Way World Town Planning Day Malaysia (2006)

15. Google Maps, https://www.google.com/maps/ 